\title{
A Walk Around Gdańsk for Physicists
}

\author{
Andrzej Januszajtis*
}

I provide a guide to Gdańsk (Danzig) and some of its suburbs, focusing on sites of particular interest to physicists. These include the Town Hall with the old Gdańsk standards of length at its entrance, the solar dial of 1588 on its corner, and its bell tower; the Naturalists Society; the medieval harbor crane; the medieval astronomical clock in St. Mary's Church; the late nineteenth-century lighthouse and time ball; and sites associated with Nicolaus Copernicus (1473-1543), Johannes Hevelius (1611-1687), Daniel Gabriel Fahrenheit (1686-1736), and Daniel Gralath (1708-1767). I also comment on the history of and physical research being carried out today at the Technical University of Gdańsk and the University of Gdańsk.

Key words: Nicolaus Copernicus; Johannes Hevelius; Daniel Gabriel Fahrenheit; Daniel Gralath; Naturalists Society; Technical University of Gdańsk; University of Gdańsk; solar dial; astronomical clock; harbor crane; lighthouse; history of Gdańsk; history of physics.

\section{A Glimpse into History}

Gdańsk (Danzig) is a large harbor city on the Baltic Sea more than one thousand years old. ${ }^{1}$ It is renowned for its beauty and dramatic history. For over seven centuries it was under the rule of Poland, enjoyed considerable autonomy, and attracted many German, Dutch, French, Scottish, and other immigrants who became merchants, artisans, and workers, and remained faithful to Poland in difficult times, for example, by supporting the city during the war with Albrecht von Hohenzollern (1490-1568) in 1519-1525 and with Sweden between 1600 and 1629, and in defending King Stanisław Leszczyński (1677-1766) when Gdańsk was besieged by the Russians in 1734. During the second partition of Poland in 1793, the resistance of Gdańsk citizens delayed the capture of the city by the Prussians. Napoleon declared Gdańsk to be a Free City in 1807, but after his downfall it again was annexed by Prussia (Germany, after its unification in 1871). Several decades of stagnation followed, after which it experienced new development.

Gdańsk again became a Free City after the Great War of 1914-1918-and a bone of contention between Poland and Germany. Two decades later, World War II began with the German attack on the Polish Munition Depot on the Gdańsk

\footnotetext{
* Andrzej Januszajtis is Docent Emeritus at the Technical University of Gdańsk and Honorary Citizen of the City of Gdańsk.
} 
harbor (Westerplatte). The war ended with the almost complete destruction of the historic inner city by the Soviet army in battles and just thereafter. After the war, Gdańsk was thoroughly reconstructed, is now as beautiful as ever, and attracts millions of tourists annually. Its ethnic character changed over time, but its spirit of freedom did not, even when it was under communist rule. Everyone knows that Gdańsk was the birthplace of the Solidarity movement whose ramifications led to the peaceful restoration of freedom in Eastern and Central European nations.

Gdańsk can be reached by plane, train, ship, or car, and has many hotels and other accommodations. Guidebooks describe its natural beauty and historical monuments and sites. I focus on those of particular interest to physicists, and extend a warm invitation to all to visit this unique city.

\section{Town Hall and Standards of Length}

We first walk to the heart of the Main or Right Town (Gtówne Miasto) and go to the Long Market (Dtugi Targ, figure 1) where the most important historical buildings and monuments are located. Foremost among these are the Gothic Town Hall crowned by its magnificent Renaissance spire of 1561 with a statue of Polish King Zygmunt II August (1520-1572) on its top, as well as the splendid King Arthur (Artus) Court dating to the Middle Ages, with its richly decorated interior and the Neptune Fountain, erected in 1633, in front of its façade. At the entrance of the Town Hall are the old Gdańsk standards of length (figure 2): the foot (equal to 28.7 centimeters), the ell (equal to $2 \mathrm{feet}$ ), and the fathom (equal to $6 \mathrm{feet}$ ), as shown by engraved lines on them. ${ }^{2}$ In 1816 , after the partitions of Poland, the Prussians replaced these with their own, slightly longer units, as shown by the lengths of the bars. These old Gdańsk standards of length are not as exact as the standard meter preserved in Sevres, France, but they are historically important, as they served to calibrate the measures of length used in trade.

\section{The 1588 Solar Dial}

Look upward at the corner of the Town Hall to see the solar dial (figure 3), which was erected in 1588 by Alexander Glaser (d. 1594), a minister at St. Barbara Church in the Long Gardens (a district of the Inner Ciry). Under the Gdańsk coat of arms one can read four kinds of hours, ASTRONOMIC, ANTIQUE, BABYLONIAN, and ITALIAN. The shadow of the small ball on the gnomon facilitates the recognition of the months: In March and September it moves along the straight line of the equinoxes; from October to February it moves on the upper concave curves; and from April to August it moves on the lower convex curves. You also can distinguish the signs of the Zodiac, which help to determine the month of the year, and read the impressive sentence, UMBRA SUNT DIES NOSTRI (Our Days are Shadows). Initially, the sundial was based on the incorrect latitude of Gdańsk, $54^{\circ} 54^{\prime} \mathrm{N}$, which archival payrolls show was corrected in 1648 to 


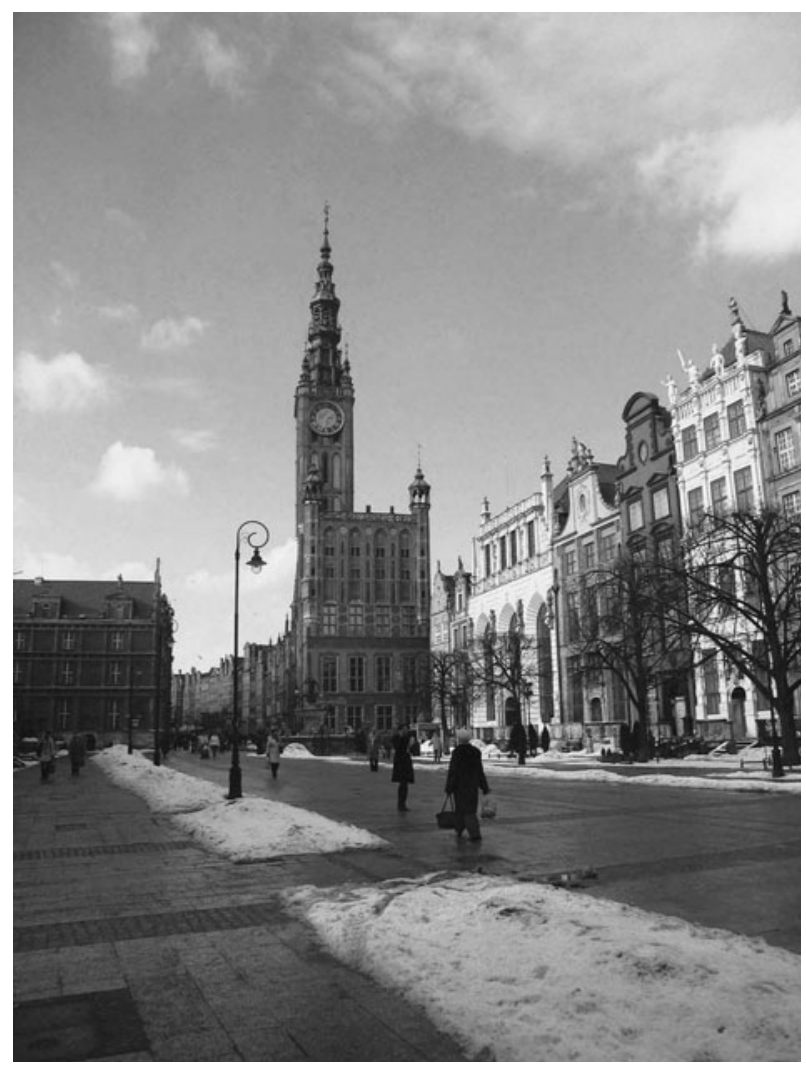

Fig. 1. The Long Market in Gdańsk, showing the Town Hall. Photograph by the author.

$54^{\circ} 21^{\prime} \mathrm{N}$ by the clockmaker Wolfgang Günther (ca. 1610-1659), who worked for the famous Gdańsk astronomer Johannes Hevelius (1611-1687). As a member of the Council of the Old Town (another district in the City of Gdańsk), Hevelius had to attend the meetings of the Right Town Council. He surely had observed the error in latitude on the sundial and moved his colleagues of the Right Town Council to correct it.

There is much to see inside the Town Hall, including the splendid Red Chamber dating to the end of the $16^{\text {th }}$ century, which is reminiscent of chambers in Venetian palaces, and the medieval frescoes in the Small Christopher Room. If you have the time (and strength) to climb the hundreds of stairs to the balcony of the tower, the effort is worth it, as the view from there is enchanting. On the way up, you can look at the keyboards of the famous carillon, which has 37 bells and is the worthy successor of the first one of 1561 , which had 14 bells, all of which were cast in Holland. ${ }^{3}$ The old bells were programmed by pins on a weight-driven 


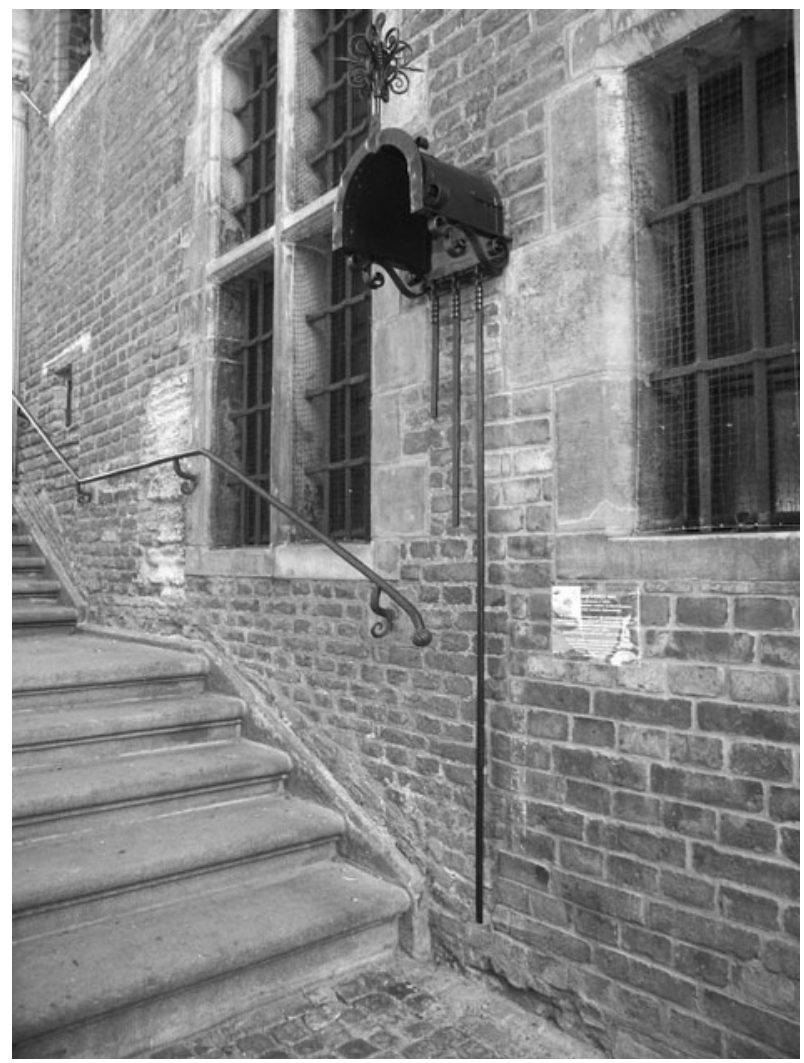

Fig. 2. The historical standards of length of Gdańsk. Photograph by the author.

rotating drum that was set in motion by the tower clock mechanism each hour on the hour. As the drum revolved, the pins raised the bell hammers by means of bars and wires, and when they dropped the bells played in a preset sequence. The tunes they played were recorded in the tower books by indicating the positions of the pins on the drum. I and a group of musicians from the Gdańsk Academy of Music managed to decipher them, so we now can listen to the old tunes played on the new bells, which are recorded on chips that control the electromagnetically driven hammers. The tunes are changed every week. There also is a special counter, with a manual and pedal that carillon virtuosi use to give regularly scheduled concerts.

\section{Daniel Gabriel Fahrenheit}

We now leave the Town Hall and walk across the square toward the Green Gate. At the corner of the narrow Mieszczańska (Burghers) Street is a monument 


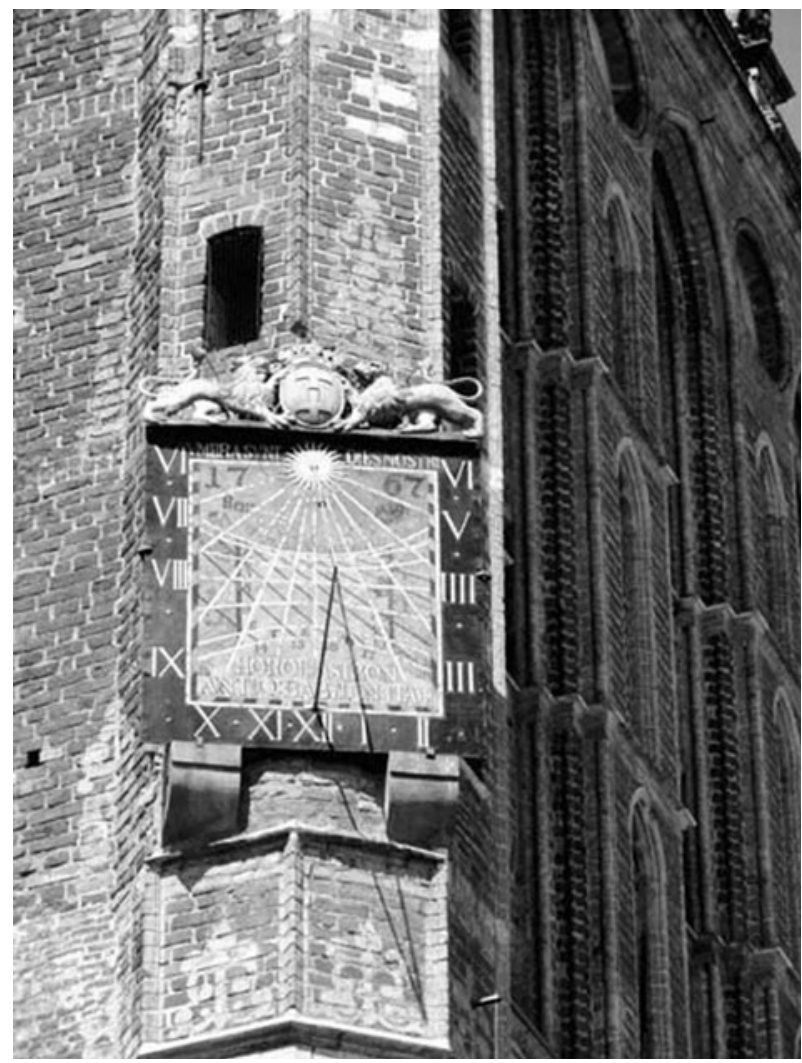

Fig. 3. The solar dial of 1588. Photograph by the author.

(figure 4) to the famous physicist Daniel Gabriel Fahrenheit (1686-1736), ${ }^{4}$ who was born in Gdańsk but spent most of his life and died in Holland, nevertheless always maintaining a connection to his native town. His greatest achievement was the construction of the first reliable thermometers, filled with quicksilver (mercury) and based upon two fixed points, the freezing and boiling points of water. He was elected as a Foreign Member of the Royal Society of London in 1724; his mastery had been extolled at its meeting on March 5, 1723:

Mr. Fahrenheit Shewed a Curious small Double Thermometer of his own invention, it was about 4 inches in Length and had two Tubes one of Quicksilver and the other of Spirit of Wine, which were fitted to a Silver frame and adjusted to a common Scale being so Contrived as to Stand at the same Common height and rise and fall Equally. ${ }^{5}$ 


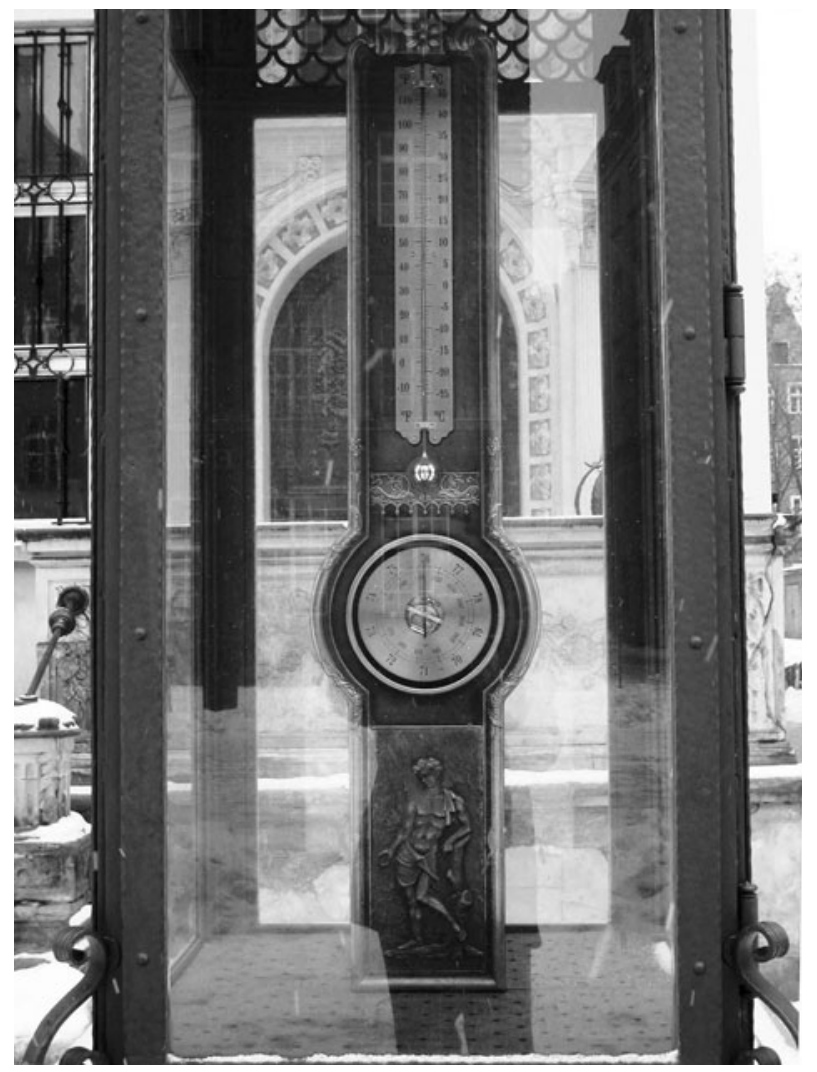

Fig. 4. The Fahrenheit monument, meteorological station. Photograph by the author.

Fahrenheit also discovered and measured the changes in the freezing and boiling points of water with atmospheric pressure. Further, he invented the cascade method of cooling, and hence may be regarded as a pioneer of cryogenics, having reached a record low temperature of 40 degrees below zero (which is identical on both the Fahrenheit and Celsius scales) in 1730. The Fahrenheit monument in the Long Market is unique: it has the shape of a meteorological station with an enlarged copy of a lost 1752 Gdańsk thermometer connected to an aneroid barometer-one of the first in the world. The temperature can be read in both Fahrenheit and Celsius degrees, and the pressure in millimeters of mercury and-as a modern addition-in hectopascals. A memorial plaque to Fahrenheit is on the rebuilt façade of his birthplace, some 100 meters up the neighboring street, at 95 Ogarna (Hound) Street. 


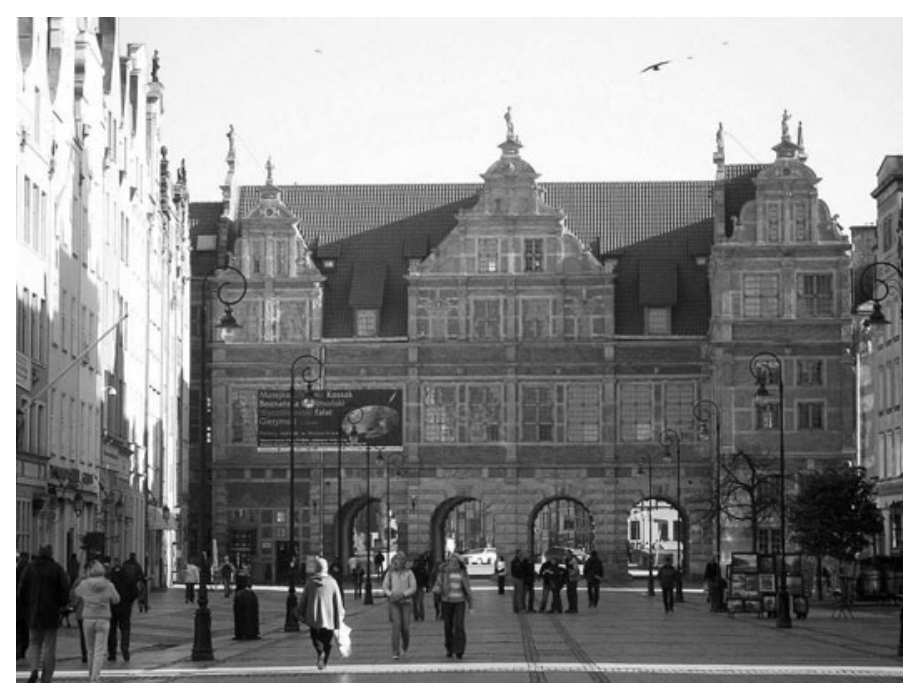

Fig. 5. The Green Gate, the former seat of the Societas Physicae Experimentalis. Photograph by the author.

\section{The Seat of the First Physical Society}

Returning to the Long Market (Dtugi Targ), we see the imposing Green Gate (figure 5), which leads to the ancient port on the Motława river. It was built in 1568 after the design of Hans Kramer (d. 1577) and was intended to be the official residence of the Kings of Poland during their visits to Gdańsk, but they preferred to stay in the sumptuous private houses of the rich Gdańsk burghers. In 1746 the palace-like Green Gate became the seat of the Gdańsk Naturalists Society (Societas Physicae Experimentalis, or Naturforschende Gesellschaft), ${ }^{6}$ which had been founded three years earlier as the world's second society with physics in its name whose aim was to promote the latest discoveries in physics.* Its members consisted of experimenters and assistants who met every Wednesday to demonstrate physical experiments to the public, after which a discussion followed. The founder of the Society, Daniel Gralath (1708-1767), ${ }^{7}$ later became Mayor (Bürgermeister) of Gdańsk. He was the first physicist in the world to write a history of electricity whose first part appeared in 1747 in the Society's Versuche und Abhandlungen, ${ }^{8}$ which he dedicated to the King of Poland. Gralath planned to transform the Society into an Academy of Sciences for all of Poland.

Based upon information Gralath received from another member of the Society, Ewald Jürgen von Kleist (1700-1748) from Kamień Pomorski (Cammin), who constructed the first electric condensers, Gralath investigated the so-called Leiden

* The first such society was the Accademia Fisico-Mathematica, founded in Rome in 1667. 
jars earlier than Pieter van Musschenbroek (1692-1761) did in Leiden, connected them together to form batteries, and explained the processes occurring in them. In 1747 Gralath also measured electrostatic forces, finding their inverse-square dependence on distance, ${ }^{9}$ but did not express this in a formula. Had he done so, we would call this Gralath's law instead of Coulomb's law, which Charles Augustin Coulomb (1736-1806) formulated a half-century later. The Swiss mathematician and astronomer Johann (Jean) Bernoulli III (1744-1807), who visited the Naturalists Society in 1770, described it as follows:

In the afternoon I spent my time from 3 p.m. until 7 p.m. in the rooms of the Physics Association in the so-called Green Gate, where several members of the truly scientific society and deserving the highest approbation met to show me, with all their patience and kindness, its fantastic natural collection. They are all kept in a beautiful and very large room in perfect order, and at the end of the room there is a very nice space where the Association holds its meetings. ${ }^{10}$

Unfortunately, this collection was destroyed in the Second World War. The Society has been revived today in Germany as the Naturforschende Gesellschaft, and its traditions are being continued in Gdańsk by the Gdańsk Scientific Society (Gdańskie Towarzystwo Naukowe), which cooperates with its counterpart in Germany.

\section{Medieval Harbor Crane}

We now go through the Green Gate and walk to the Green Bridge over the Motława river. Standing on the bridge, we admire the beautiful view of the Old Harbor, which has been marvelously reconstructed after its terrible destruction at the end of the Second World War. Its reconstruction, however, has not yet been completed: The row of famous granaries on the right embankment has not yet regained its unique architectonic shape. They will no longer store grain, but will house hotels, restaurants, museums, offices, and private apartments.

On the left we see the magnificent Long Bridge (that is, Long Quay) with its eight water gates (figure 6). Since the Middle Ages, each main street in the Right Town led to the Old Harbor and ended in a water gate. In the distance, we see one of them with an unusual wooden structure superposed on it. This is the famous crane that dates to 1444, the largest one that was erected in medieval Europe. Its mechanism (figure 7) consists of two pairs of wooden drums, 6 and 6.5 meters in diameter, one pair above the other one, each drum with steps inside it on its circumference, which forms the lifting mechanism, a vertical treadmill, that is, a windlass, on which three workers inside each drum climbed. If we assume that the average weight of each worker was 70 kilograms, his average distance to the drum's axis was 1.3 meters, and the diameters of both central wells (on which the ropes of the lifted cargo are wound) are 0.50 meter, we find that the lifting capacity of the crane was a little over 4 metric tons (4000 kilograms), which could be raised 


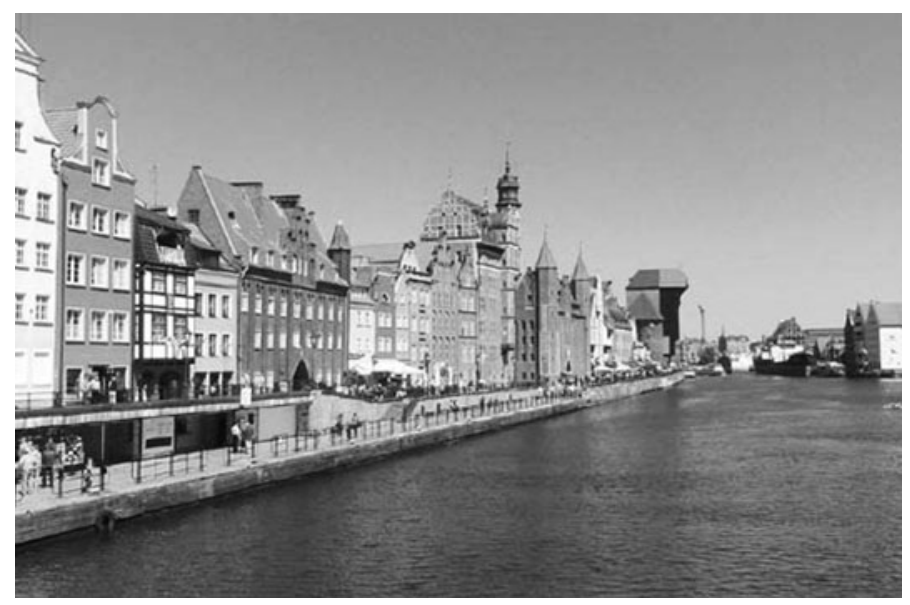

Fig. 6. The Long Bridge (Long Quay) with the medieval crane in the background. Photograph by the author.

to a height of 11 meters, or, if only the upper drums were used, 2 metric tons $(2000$ kilograms), which could be raised to a height of 27 meters. The wooden machinery, which was destroyed by fire during the Second World War, has been reconstructed, and the rebuilt crane is now part of the attractive Maritime Museum, which extends to the rebuilt granaries on the opposing Otowianka (Lead Year) island.

\section{The Naturalists House}

Walking along the Long Quay and looking at the water gates, we see a landscape of beautiful façades with terraces (porches) in all styles of the past that were typical of Old Gdańsk. On Chlebnicka (Bread Benches) Street we can admire the English House, a seven-story building constructed in 1570-a Renaissance skyscraper, which reminds us of the more than 800 English merchants who lived in Gdańsk in the $17^{\text {th }}$ and $18^{\text {th }}$ centuries and even had their own Methodist Chapel, which unfortunately no longer exists.

The next street, Mariacka (St. Mary's) Street (figure 8), is surely one of the most beautiful streets in the world, with a terrace and steps in front of every house. Their old entrance halls have been transformed into shops or cafes, with some small ones even in the cellars under the terraces. The end of the street is closed by St. Mary's Church; at the other end, alongside the water gate on the harbor, is an unusually tall house that Antoni van Obberghen (1543-1611) built in 1599 (figure 9), a decade and a half after he had built Hamlet's famous castle in Elsinore for King Frederick II (1534-1588) of Denmark-Norway in 1574-1584. The building now houses the Archeological Museum. 


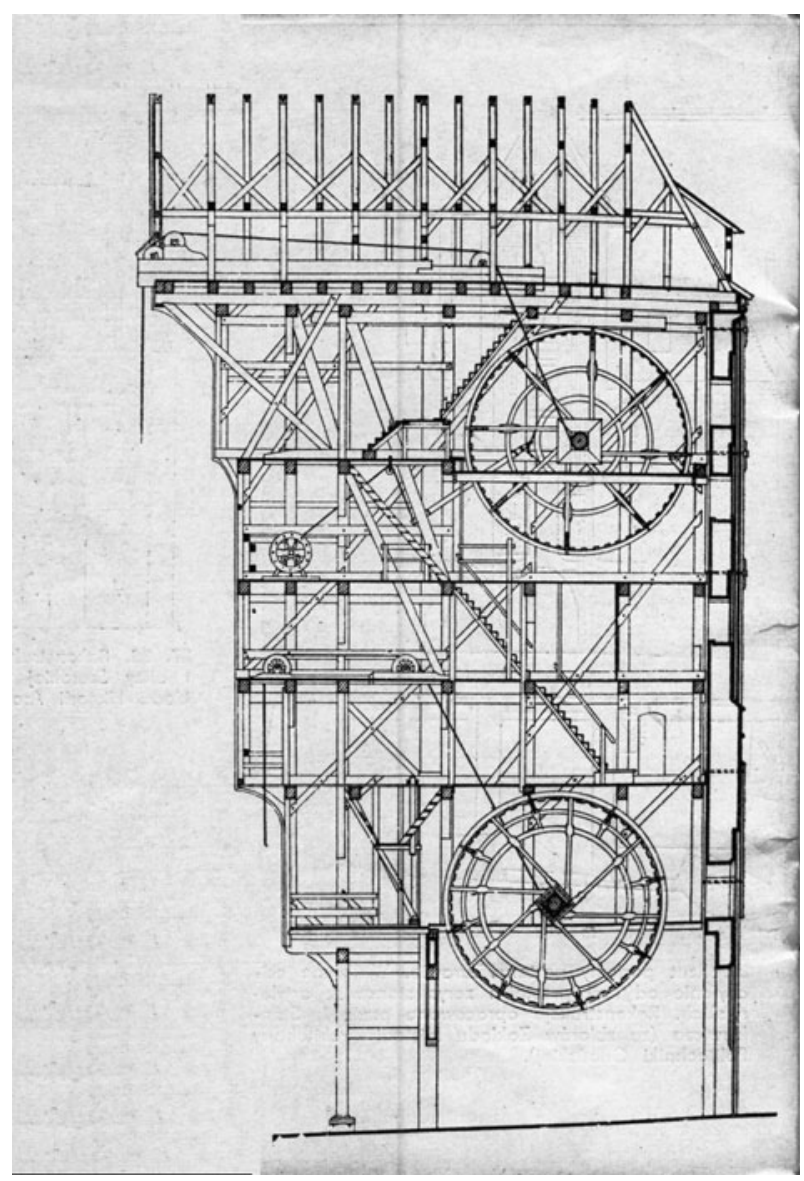

Fig. 7. Cross section of the medieval crane. Source: Januszajtis, "1000 Years" (ref. 1), p. 146.

For an entire century, however, from 1845 to 1945, this building was the headquarters of the Naturalists Society. In 1866, the Society built an astronomical observatory on the top of its tower, which was destroyed in the Second World War. Among the Society's foreign members were such celebrities as Johann Reinhold Forster (1729-1798) who with his son Georg (1754-1794) took part in the second expedition of James Cook (1728-1779) around the world; the polymath Alexander von Humboldt (1769-1859); the astronomers Johann (Jean) Bernoulli III (1744-1807), Johann Encke (1791-1865), and Friedrich Struve (1793-1864); the mathematician Friedrich Bessel (1784-1846); and the physicists Hans Christian Oersted (1777-1851) and François Jean Dominique Arago (1786-1853). When the first report on Foucault's pendulum reached Gdańsk, Society scientists repeated the experiment and announced a prize competition for its explanation. Its winner 


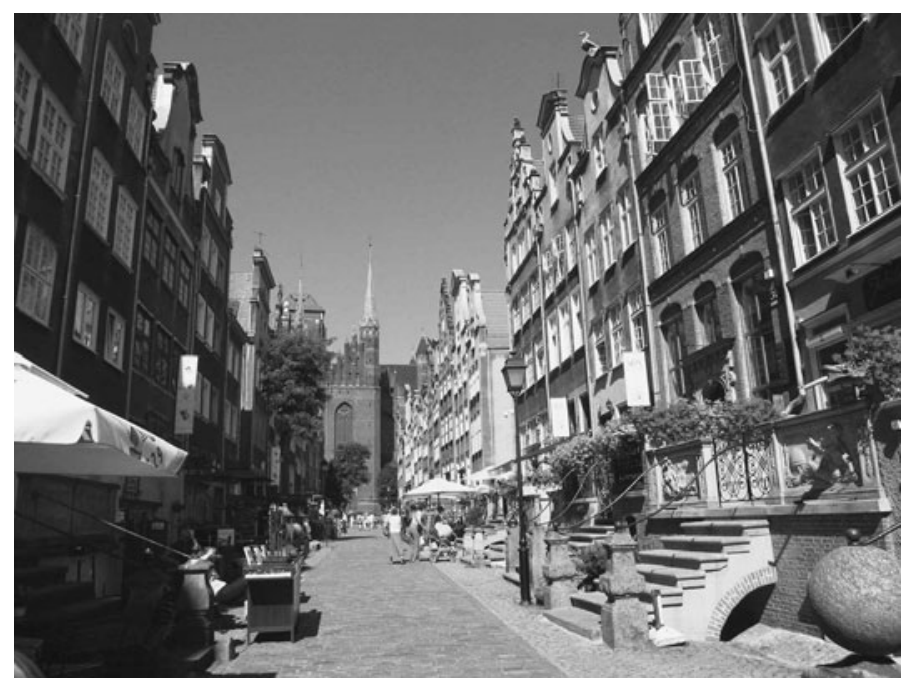

Fig. 8. Mariacka (St. Mary's) Street. Photograph by the author.

was Peter Andreas Hansen (1795-1874) from Gotha, who developed equations to describe its motion. ${ }^{11}$

One of the specialties of the Society was the investigation of amber-Baltic Gold-and of ancient amber-bearing trees. Today, in the old Torture Chamber and Prison Tower at the entrance to Dtuga (Long) Street, is the Amber Museum with a collection of international significance, including the famous small lizard that was captured in viscous resin-today's amber-forty million years ago. Amberware is sold in many shops on the Long Quay and Mariacka (St. Mary's) Street.

\section{Copernicus Connections}

Nearby, in the shadow of St. Mary's Church, is the Old Vicarage (figure 10), which was founded by the parson Mauritius Ferber (1471-1537) in 1518 to replace the much older one dating to the $14^{\text {th }}$ century. Later, when Ferber became Bishop of Warmia (Ermland), he nominated Nicolaus Copernicus (1473-1543) as his secretary, who had many connections to Gdańsk. His mother's relatives, the von Allens, lived in Gdańsk, and both Ferber and his successor as Bishop of Warmia, Johannes Dantiscus (1485-1548), whom Copernicua also served as secretary, were born in Gdańsk, as was Copernicus's friend and protector Tiedemann Giese (1480-1550), Bishop of Chełmno (Kulm).

Copernicus lived in Frombork (Frauenburg) not far from Gdańsk, and visited Gdańsk on at least four occasions. Moreover, after 1538 the famous Flemish 


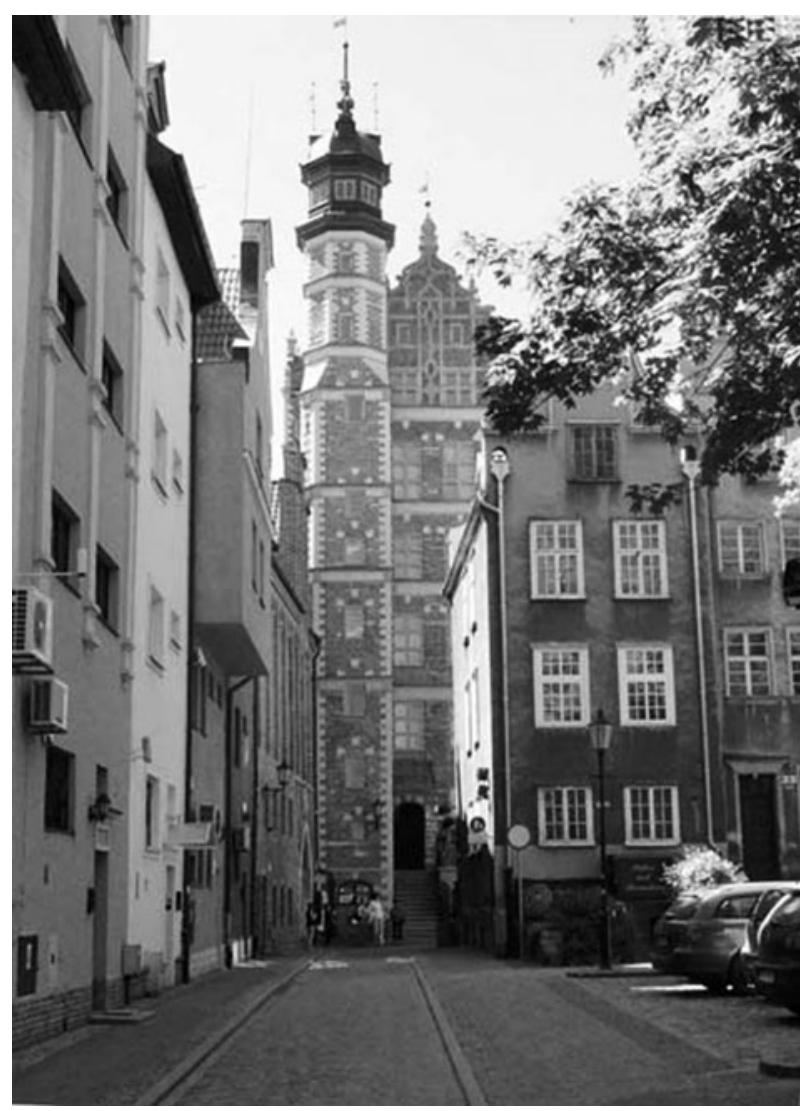

Fig. 9. The Naturalists House, today the Archeological Museum. Photograph by the author.

printer Franz Rhode (d. 1559) worked in Gdańsk, so when the young Austrian mathematician Georg Joachim Rheticus (1514-1574) visited Copernicus and obtained his agreement to announce the publication of his heliocentric system, Rheticus went to Rhode, engaging him to print his treatise, the Narratio prima (First Account), which appeared in Gdańsk in 1540, three years prior to the publication of Copernicus's De revolutionibus in Nuremberg. Rheticus's Narratio prima contains several valuable biographical details about Copernicus that he had learned directly from the great astronomer. In 1539, while awaiting the publication of his Narratio prima, Rheticus measured the magnetic declination in Gdańsk, finding it to exceed $13^{\circ} \mathrm{E}$, which was the third such measurement in the world. 


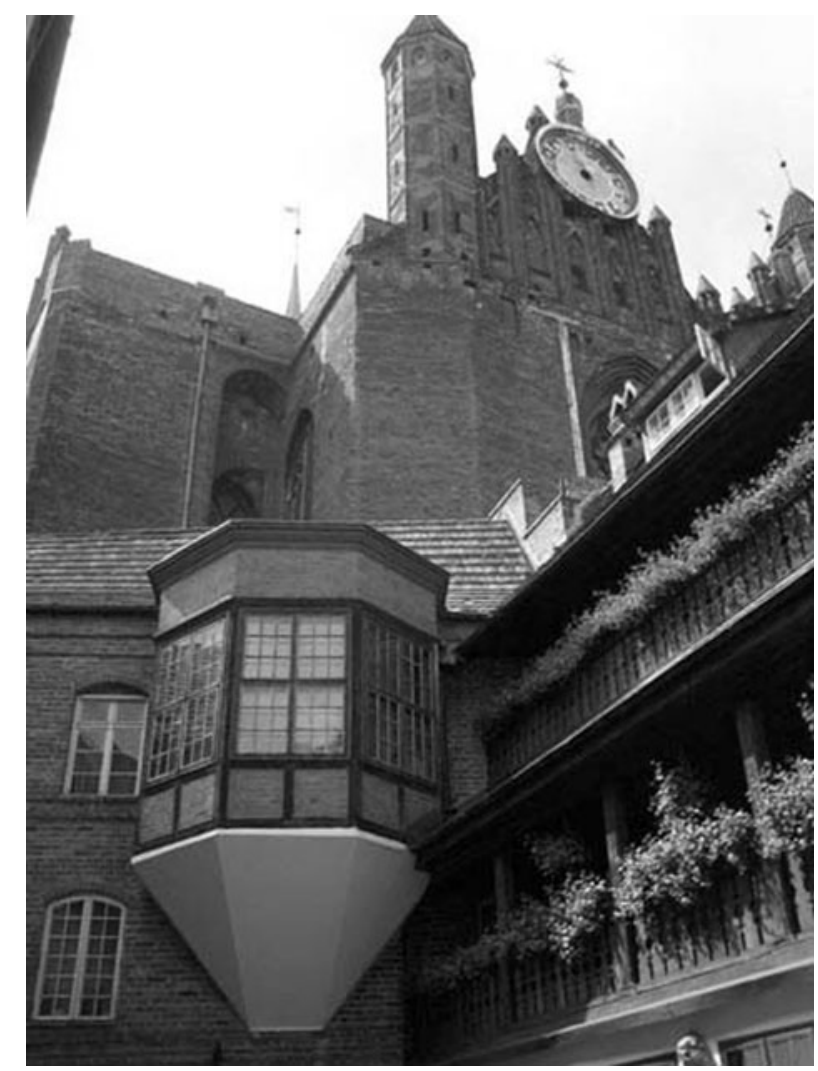

Fig. 10. The courtyard of the Old Vicarage. Photograph by the author.

\section{Medieval Astronomical Clock}

Among the treasures in St. Mary's Church-the world's largest church built entirely of bricks-is the giant astronomical clock (figure 11) that Hans Düringer (d. 1477) from Torun (Thorn) on the Vistula river constructed in $1470 .{ }^{12}$ It is the largest astronomical clock that was constructed in medieval Europe. Restored after the Second World War, it is a brilliant witness to the high level of astronomy in medieval Gdańsk. In addition to the hours, it indicates the positions of the Sun and Moon in the Zodiac and the phases of the Moon. The dates of New Moon can be read on the large calendar dial, as calculated in the $15^{\text {th }}$ century with an error not exceeding a few minutes. The learned priests of St. Mary's assumed (following Ptolemy's Almagest) that there are 235 lunar cycles in 19 years, which led to a synodic month of 29 days, 12 hours, 44 minutes, and 3 seconds, that is, one that is only 0.11 second too short. 


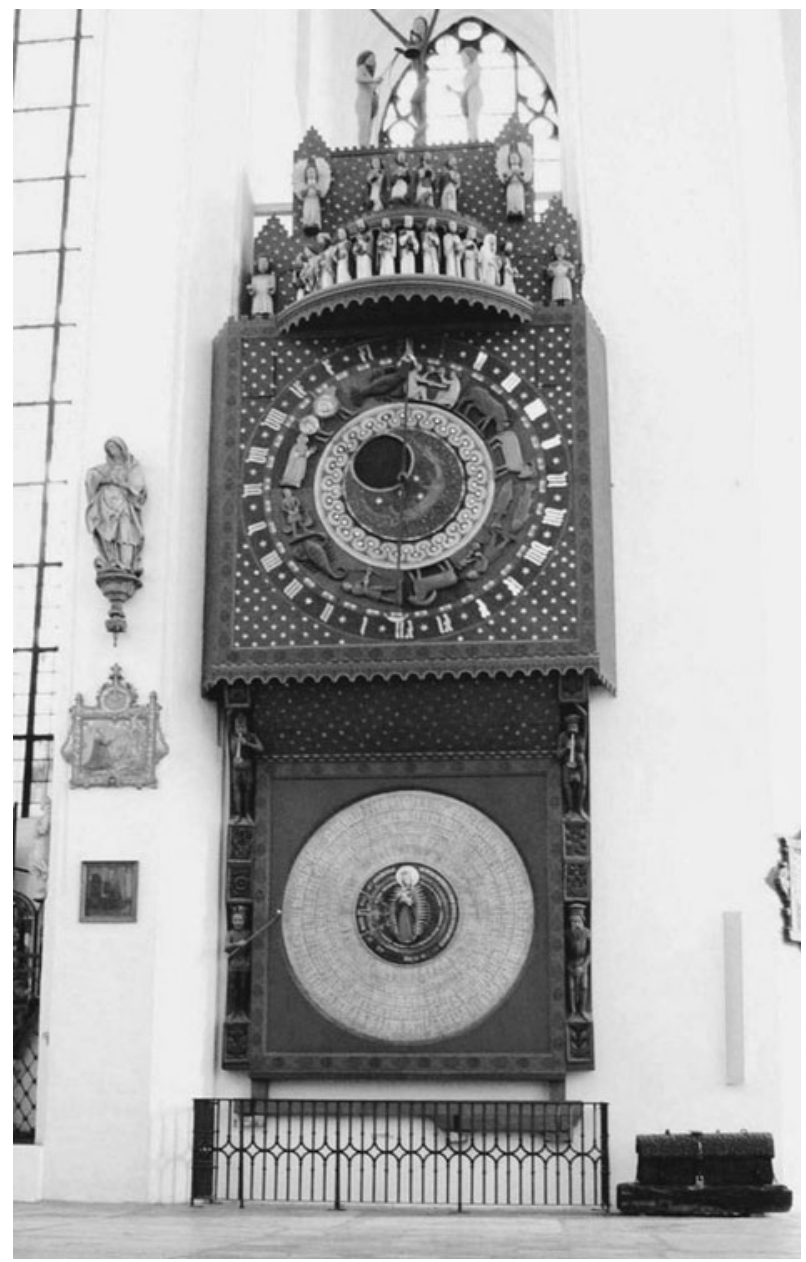

Fig. 11. The Astronomical Clock of 1470 in St. Mary's Church. Photograph by the author.

The ingenious system to indicate the phases of the Moon consists of an external dial that moves together with the Sun's plate once around the Zodiac in one tropical year, and an internal dial that is connected to the Moon's plate, which makes one complete revolution in one sidereal month. The internal dial is divided into two fields, black and golden, while the external dial has an oval opening through which part of the surface of the internal dial can be seen. Their combined movements change the proportions of the black and golden fields of the internal dial in the oval opening of the external dial with a periodicity of one synodic month. At New Moon, the field in the oval opening is black; at Full Moon, a serene 
golden face appears. To construct the mechanism driving the dials, the clockmaker also used the astronomical values in Ptolemy's Almagest.

There is much else to see in St. Mary's Church, including 13 gothic altars, 32 epitaphs, and the great organ (from St. John's Church) bearing on its casing of 1629 the legend of Old and Young Tobias.

\section{Doctors and Philosophers}

We now leave St. Mary's Church and walk to the corner of Piwna (Beer) Street and Kozia (Goat) Street where we see the former house (figure 12) of Johan Schmiedt (1624-1690), who in 1666 became the third physician in Europe to make intravenous injections. At the end of Piwna (Beer) Street we can admire the Great Arsenal, one of the best examples of Dutch Renaissance architecture and the greatest work of Antoni van Obberghen (1543-1611), which he completed in 1609. Farther north we pass Świętego Ducha (Holy Ghost) Street, where at the present number 47 the philosopher Arthur Schopenhauer (1788-1860) was born. On Świętojańska (St. John's) Street, we can visit St. Nicholas's Church, the only church in Gdańsk that was not destroyed in the Second World War. Among its rich furnishings-baroque altars, a magnificent organ dating to 1755-we find the epitaph of the physician Johannes Scheffler (1624-1677), who in 1665 coauthored the first pharmacopea in Poland.

We now are close to the Market Hall of 1898, but we should not be deceived by its late construction date: In its cellar the foundation of the first St. Nicholas's Church, which dates to the end of the $12^{\text {th }}$ century, was discovered and can be viewed.

\section{In the Footsteps of Johannes Hevelius}

We now leave the Right (or Main) Town, cross Podwale Staromiejskie (Old Town Wall) Street, and enter the historic Old Town. Directly in front of us we see St. Catherine's Church with its splendid tower, from which the peal of its 50 bells resound. In its presbytery is the tomb of Johannes Hevelius (1611-1687), ${ }^{13}$ whose epitaph is on a pillar above it (figure 13).

Hevelius was the greatest astronomer in Poland after Copernicus. He studied in Leiden from 1630 and travelled in the following years to England and France where he established contact with leading scientists with whom he corresponded throughout his life (twelve thousand of his letters are preserved in French archives). After returning to Gdańsk, he married and moved from the Right Town, where his parents lived, to the Old Town, where he had a brewery that brought him financial independence and enabled him to devote his life to astronomy. He constructed a large observatory on the roofs of his houses in Korzenna (Pepper) Street that extended over an area of 200 square meters. ${ }^{14} \mathrm{He}$ equipped his observatory with several telescopes, becoming one of the first astronomers in the 


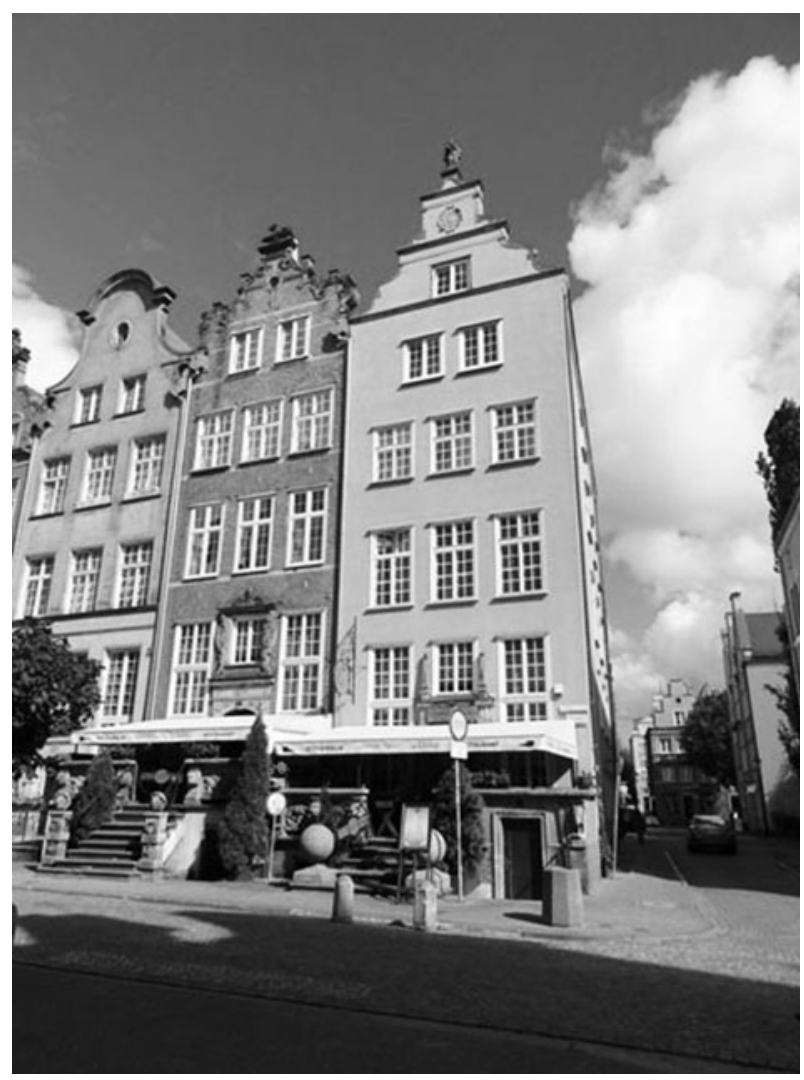

Fig. 12. The former house of the physician Johan Schmiedt (1624-1690). Photograph by the author.

world to do so, whose focal lengths ranged from 25 to 70 feet, which he began operating systematically in 1641 . He tried to set up a 140 -foot telescope outside of his observatory, but it was too sensitive to wind currents to be used. He also used older instruments, including a beautiful sextant he had inherited from his teacher Peter Krüger (1580-1639). He became an Alderman and later a Councilor of the Old Town. After 1663 he was assisted by his second wife, Elisabeth Koopman (1647-1693), his junior by 36 years, who may be regarded as the first female astronomer in Poland. ${ }^{15}$

Hevelius's prodigious output consists of 19 treatises, 29 dissertations, and 16 volumes of correspondence. His Selenographia, published in 1647, contains precise descriptions and maps of the Moon that were unsurpassed for two centuries. His two-volume Machina Coelestis of 1673 and 1679 describes his instruments and their uses, for example, the use of a micrometer screw to achieve precision 


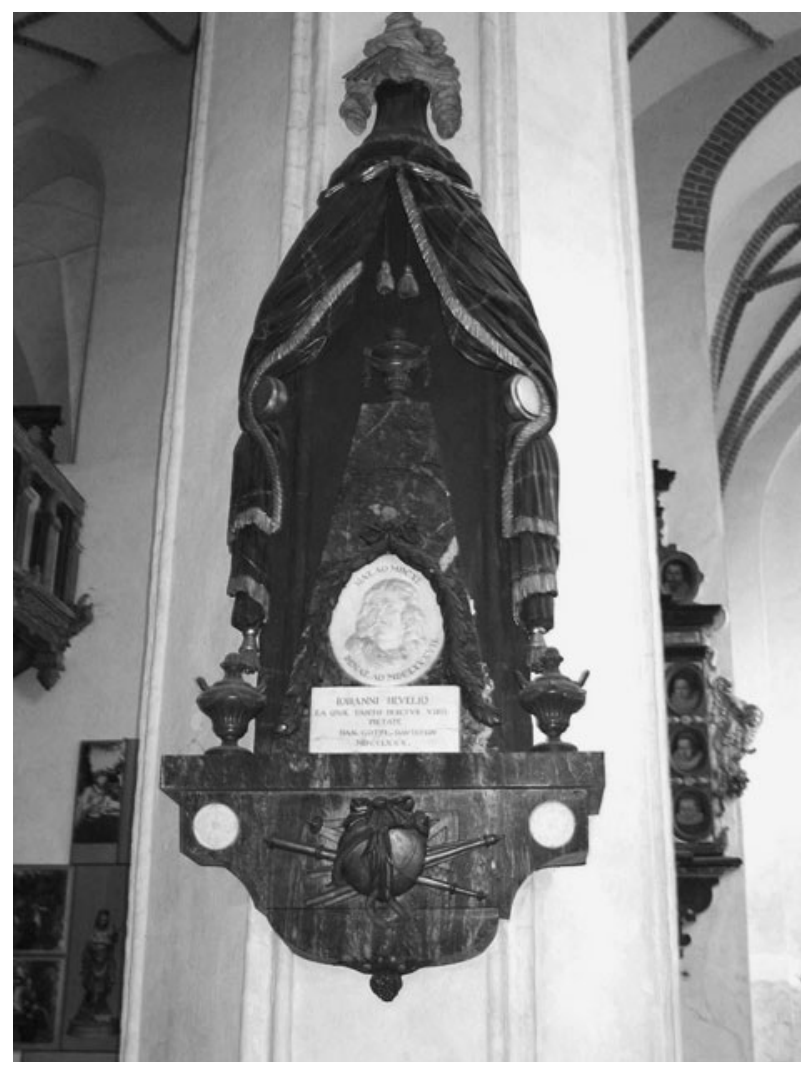

Fig. 13. The epitaph of Johannes Hevelius (1611-1687) in St. Catherine's Church. Photograph by the author.

settings. He also invented the periscope, which he called a polemoscope. Under his guidance, the clockmaker Wolfgang Günther (ca. 1610-1659) constructed the first pendulum clocks at the same time as did his famous Dutch contemporary Christiaan Huygens (1629-1695).

In 1664 Hevelius became one of the first scientists to be elected as a Foreign Member of the Royal Society of London. A decade and a half later, in 1679, the Royal Society sent the English astronomer Edmond Halley (1656-1743) to Gdańsk to confirm the accuracy of Hevelius's observations. In 1690, three years after Hevelius died, his widow published his Prodromus Astronomiae, which gave the positions of 1564 stars that he had determined to high accuracy, aa well as his Firmamentum Sobiescianum, which contained 56 maps of the sky with beautiful engravings of constellations to which he had added 9 new ones, for example, Scutum Sobiescianum (Sobieski's Shield), a name he chose as a means of thanking Polish King Jan III Sobieski (1629-1696) for financial support. 


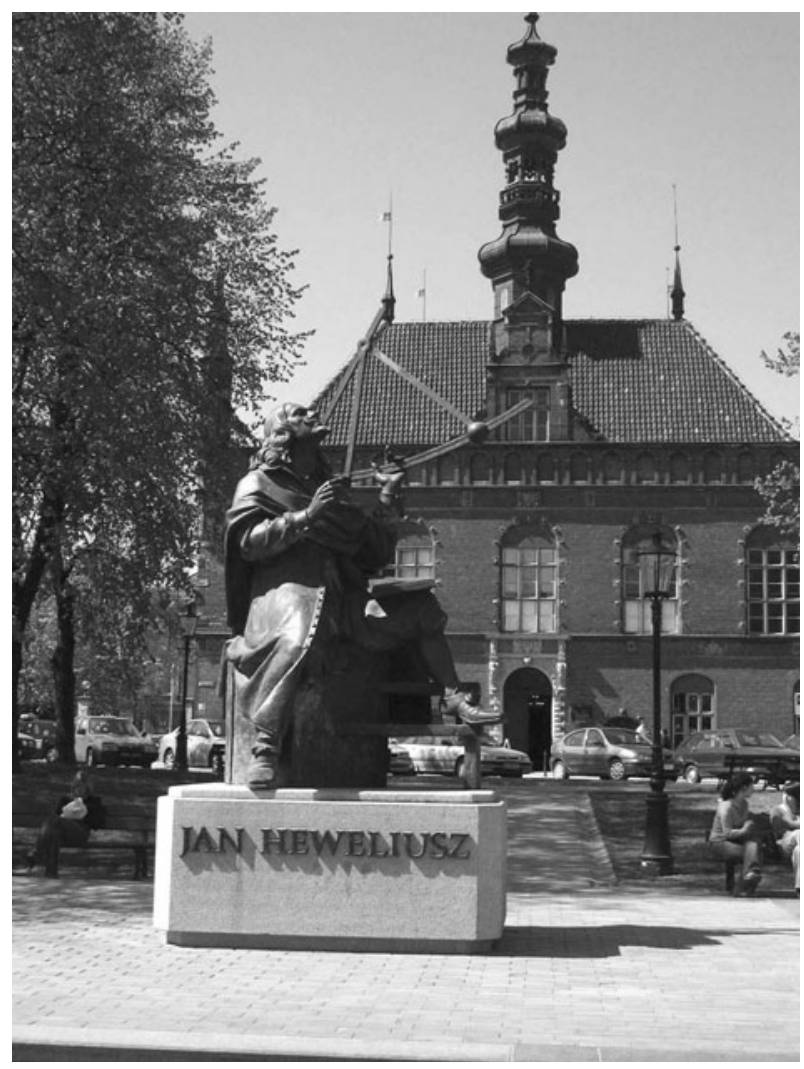

Fig. 14. The monument to Johannes Hevelius (1611-1687). Photograph by the author.

Hevelius also continued to measure the magnetic declination in Gdańsk and discovered its secular changes. Another Polish King, Jan II Kazimierz (1609-1672), rightly claimed that Hevelius "will be the ornament and pride of Gdańsk in the centuries to come," 16 as future generations confirmed. They erected an impressive monument to Hevelius in front of the Town Hall in the Old Town (figure 14). The Town Hall, built by Anthoni van Obberghen (1543-1611) in 1594 and not destroyed in the last war is very worthwhile visiting. In its two-story cellars Hevelius used to store his beer. In the large Hall on the upper floor he attended assemblies and sessions of the court.

Teachers today take their students on walking tours following in the footsteps of Hevelius. An astronomical observatory has been constructed on the roof of the Autonomous School on Osiek (Abatis) Street, not too far from the ancient Hevelius's houses. On Grodzisko or Gradowa (Hail) Hill overlooking the Main Railway Station, a center for the popularization of science has been opened for the 
youth of Gdańsk; it has been named the Hevelianum in honor of the great astronomer of Old Gdańsk.

\section{The Former Academic Gymnasium and Present National Museum}

We next visit the ancient Franciscan monastery, which today houses the National Museum (figure 15) located on Toruńska Street in the Old Suburb. After the Reformation, the monks who had built the monastery in the $15^{\text {th }}$ century were compelled to transfer it to the City Council, who first converted it into a secondary school and then, in 1580, into the Academic Gymnasium. In 1596 the famous Gdańsk Library was added-which now belongs to the Polish Academy of Science and is in a newer building in Wałowa (Wall) Street. Many famous scientists taught or studied in the Academic Gymnasium, the most universal one being Batholomeus Keckermann (1572-1609), who lectured and published on logic, mathematics, geometry, optics, astronomy, geography, ethics, politics, economics, philosophy, metaphysics, rhetoric, and physics. His Systema physicum, published in Gdańsk in 1610, went through several editions, including foreign ones. His colleague, the astronomer and mathematician Peter Krüger (1580-1639), was the first to formulate the law of cosines and to elaborate logarithmic tables in which the logarithms of trigonometric functions were separated from those of numbers. ${ }^{17}$. The geographer Philip Clüver (1580-1622), who later became a professor in Leiden and founded the field of historical geography, set the eastern border of Europe as the Ural river. Heinrich Kühn (1690-1769) created a prototype of

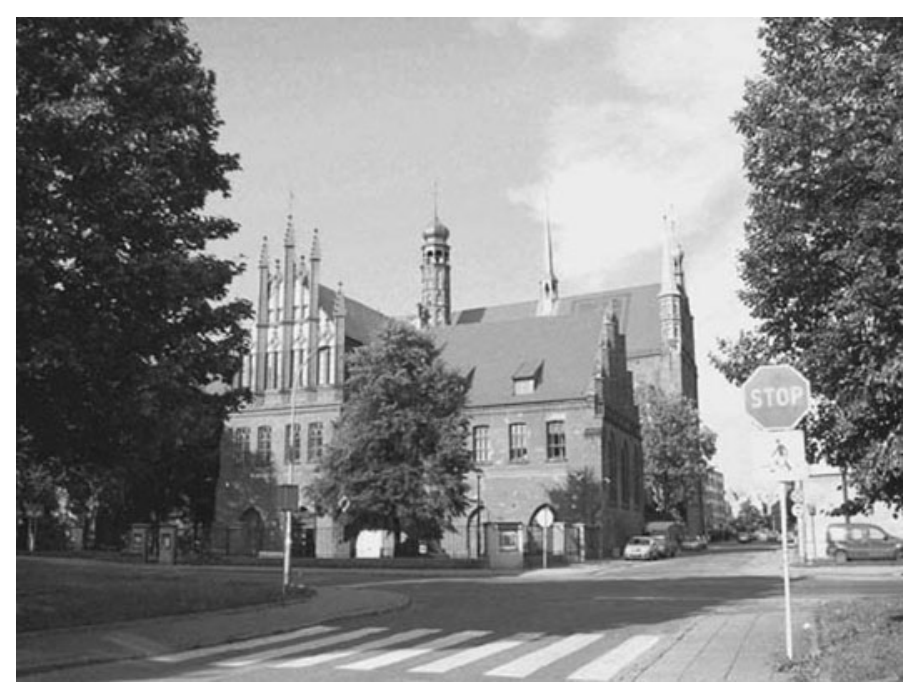

Fig. 15. The former Academic Gymnasium, today the National Museum. Photograph by the author. 


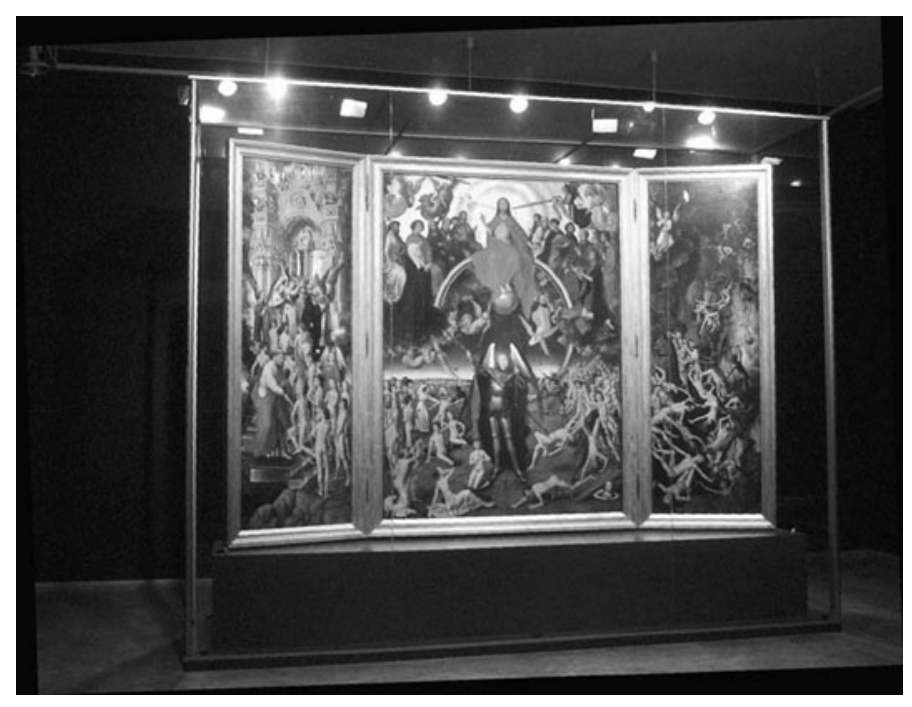

Fig. 16. The Last Judgement by Hans Memling (ca. 1430-1494). Photograph by the author.

analytical scales and proposed the first geometrical interpretation of imaginary numbers. ${ }^{18}$ In 1711 Paul Pater (1656-1724) founded the first technological school in Gdańsk where he taught the construction of scientific instruments and for some time collaborated with Fahrenheit.

Today, of the numerous masterpieces of art in the National Museum, perhaps the most compelling one for physicists is The Last Judgment (figure 16) by the German painter Hans Memling (ca. 1430-1494). The scene it depicts is reflected from the armour of Archangel Michael, as if from convex mirrors, and from the shiny ball under the feet of Christ. The master Memling seems to have been a good observer of optical phenomena, as is also evident in the double rainbow he painted in the sky.

On Bishop Hill overlooking this part of Gdańsk another astronomical observatory was constructed in 1780 by Nathanael Wolf (1724-1784), who was a court doctor for noble Polish families and a member of the Naturalists Society. His observatory acquired a high European reputation for its accurate observational results. It was destroyed by the Russians during the siege of Gdańsk in 1813.

\section{The Technical University of Gdańsk}

The Technical University of Gdańsk (Politechnika Gdańska, figure 17) was founded as a German Technische Hochschule in 1904 and was transformed into the present institution after the Second World War. Among the famous scientists there prior to the war were such celebrities as the mathematician Hans von 


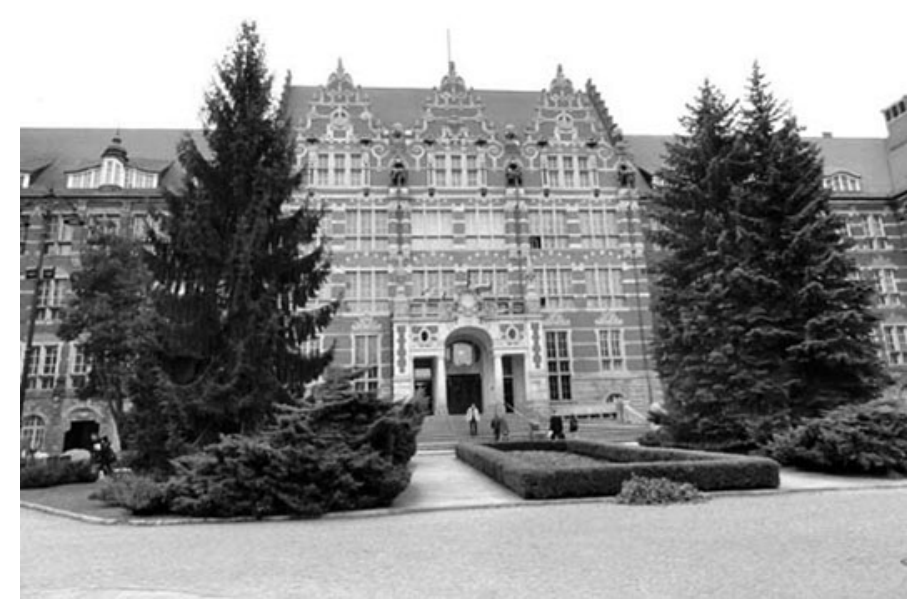

Fig. 17. The Main Building of the Technical University of Gdańsk (Politechnika Gdańska). Photograph by the author.

Mangoldt (1854-1925), the biochemist and Nobel Laureate in Chemistry for 1939 Adolf Butenandt (1903-1993), and the physicists Carl Ramsauer (1879-1955) and Walter Kossel (1888-1956). After its complete reorganization after the war, among the physicists there were Ignacy Adamczewski (1907-2000), founder of the Gdańsk School of Dielectric Liquids, and for some time Arkadiusz Piekara (1904-1989), another internationally known expert on dielectrics. The present Faculty of Technical Physics and Applied Mathematics specializes in solid-state physics, energy conversion, nanotechnology, and applied informatics. ${ }^{19}$ A new computer center has been constructed; it is the largest one in academia in Poland and publishes its well-known scientific bulletin, the TASK Quarterly, in English. At present, the Technical University has almost 20,000 students.

Besides modern equipment, the Technical University houses an excellent collection of old scientific instruments and a new Foucault pendulum (length 26 meters, weight 64 kilograms) whose oscillations (period 10.2 seconds) are maintained electromagnetically (figure 18). A laser tracks the rotation of the Earth; one complete revolution of the pendulum's plane of oscillation takes 29 hours, 32 minutes, and 6.5 seconds in Gdańsk.

A second center of physical research, although much younger than the Technical University, is the University of Gdańsk, located in the suburb of Oliwa, which Alexander von Humboldt (1769-1859) once called the third most beautiful place in the world. The research fields of its Faculty of Mathematics and Physics include atomic and nuclear spectroscopy, acoustics, and astrophysics. 


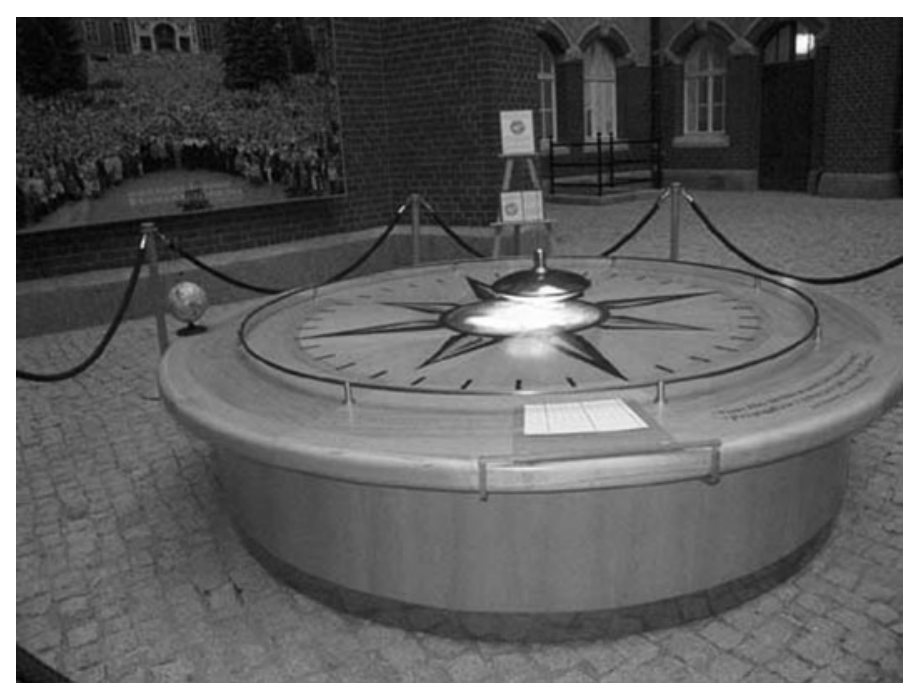

Fig. 18. The Foucault pendulum. Photograph by the author.

In addition to these universities, a visit to the Cathedral with its famous organ, one of the largest in Poland, is very worthwhile. The Cathedral is also located in Oliwa and formerly was the Cistercian Abbey, founded in 1186, where the monks had a printing shop in which scientific books and papers also were printed. These included the world's first account of the supercooling of liquid, which the Gdańsk physician Israel Conrad (1634-1715) observed in 1670, and the less-serious Physica Curiosa that the Jesuit Adalbert Tylkowski (his exact birth and death years are unknown) edited in 1680 as Part VI of the Philosophia curiosa, which attracted great interest in Europe. The Abbey's magnificent park and its surrounding wooded hills and valleys abound in enchanting sights. Also worthwhile is a visit to the Zoological Garden, the largest one in Poland, which is also located in this enchanting district of Gdańsk.

\section{The Lighthouse and Time Ball}

Last but not least, I recommend an excursion to Gdańsk's Nowy Port (New Harbor), the largest port in Poland and the deepest one on the Baltic sea. Especially interesting for physicists is the historic lighthouse, which was constructed in 1894 as a copy of a lighthouse in Cleveland, Ohio (which no longer exists). It operated until 1984, when it was replaced by a new lighthouse on Gdańsk's Northern Harbor, the deepest harbor on the Baltic sea. The old lighthouse today is a private museum (figure 19) where one can admire well-preserved lamps, large Fresnel lenses, and the reconstructed time ball, which was released by hand and dropped exactly at noon, serving as an optical time signal for chronometers aboard 


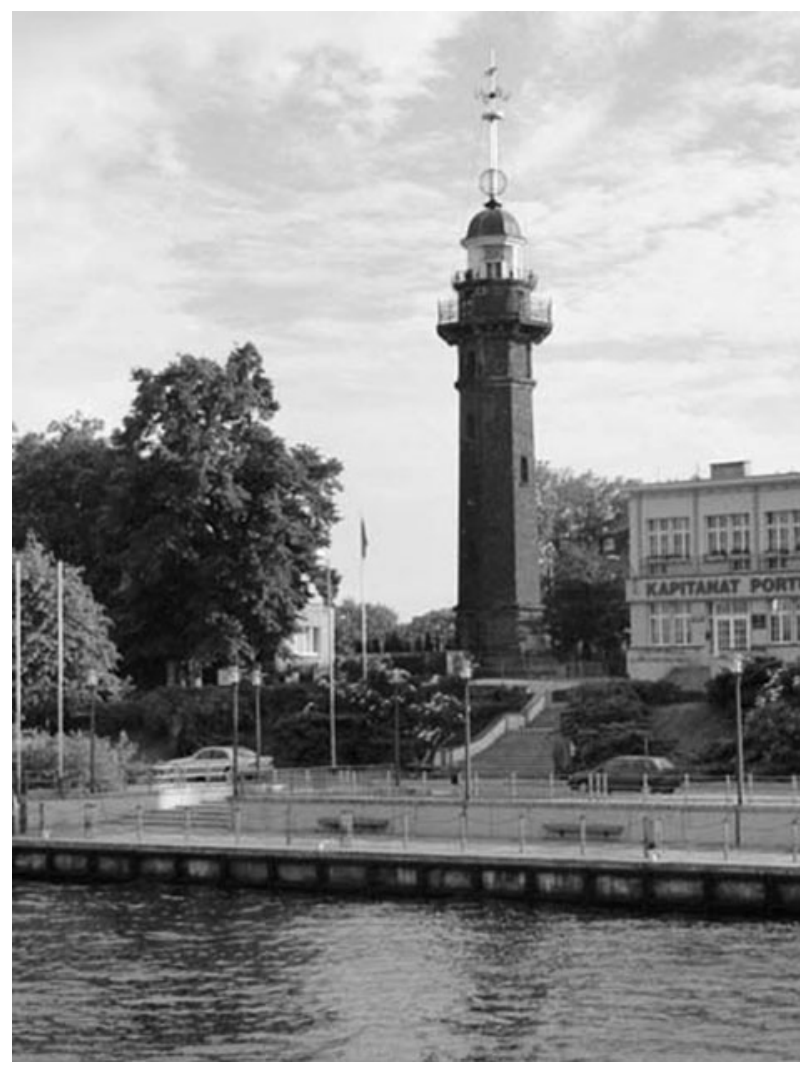

Fig. 19. The light house in New Port (Nowy Port) with the time ball. Photograph by the author.

ships in the harbor. Today, the time ball is released every two hours by an electrical pulse sent out by the European Time Service.

Gdańsk's Baltic sea coast is most attractive; its beautiful sandy beaches are over 20 kilometers long, and walkers can collect amber on them: Not in vain has it always been called the Amber Coast.

\section{Acknowledgment}

I thank Roger H. Stuewer for his thoughtful and careful editorial work on my paper.

Open Access This article is distributed under the terms of the Creative Commons Attribution Noncommercial License which permits any noncommercial use, distribution, and reproduction in any medium, provided the original author(s) and source are credited. 


\section{References}

${ }^{1}$ Andrzej Januszajtis, “1000 Years of the Harbour of Gdańsk,” TASK Quarterly 3, No. 1 (1999), 141-153.

2 Andrzej Januszajtis: “The Gdańsk Pioneers of Metrology,” TASK Quar. 2, No. 4 (1998), 733-745, especially 737-738.

${ }^{3}$ Andrzej Januszajtis, “The Bells of Gdańsk and their Music," TASK Quar. 3, No 4 (1999), 489-508, on 494; idem, Gdańskie zegary, dzwony i karyliony [The Gdańsk Clocks, Bells, and Carillons] (Gdańsk: Pelplin, 2003), pp. 117-148.

${ }^{4}$ Andrzej Januszajtis, "Gdańscy pionierzy Fizyki [Gdańsk Pioneers of Physics],"Studia i Materiały z Dziejów Nauki Polskiej. Seria C. Historia Nauk Matematycznych, Fizyko-Chemicznych i Geologiczno-Geograficznych 20 (1975), 13-26, especially 19-22; idem, Gdańsk Pioneers of Metrology" (ref. 2), pp. 739-741; idem, "Scientists in Old Gdańsk: $17^{\text {th }}$ and $18^{\text {th }}$ Centuries," TASK Quar. 5, No. 3 (2002), 389-399, especially 389-390; Andrzej Januszajtis, Mr. Fahrenheit, dżentelmen z Gdańska [Mr. Fahrenheit, Gentleman of Danzig] (Gdańsk: Towarzystwo Gdańsk-Niderlandy, 2005); see also Pieter van der Starr, Fahrenheit's Letters to Leibniz and Boerhaave (Leiden: Museum Boerhaave and Amsterdam: Rodopi, 1983).

${ }^{5}$ Minutes, Royal Society of London, March 5, 1723, reproduced in Januszajtis, Mr. Fahrenheit (ref. 4), p. 81.

${ }^{6}$ E. Schumann, "Geschichte der Naturforschenden Gesellschaft in Danzig 1743-1892," Schriften der Naturforschenden Gesellschaft in Danzig. Neue Folge. Achter Band. Zweites Heft (Danzig: Commissions Verlag von Wilhelm Engelmann in Leipzig, 1893), pp. 2-14; Andrzej Januszajtis, "Societas Physicae Experimentalis - The first Physics Society in Poland. The Origins of the Society," TASK Quar. 6, No. 2 (2002), 323-330.

${ }^{7}$ Schumann, "Geschichte“(ref. 6), p. 3; Januszajtis, "Societas Physicae Experimentalis" (ref. 6), pp. 327-328; idem, "Gdańscy pionierzy Fizyki“(ref. 4), pp. 22-25; idem, "Scientists in Old Gdańsk: $17^{\text {th }}$ and $18^{\text {th }}$ Centuries" (ref. 4), pp. 392-393.

${ }^{8}$ Daniel Gralath, "Geschichte der Elektrizität," Versuche und Abhandlungen der Naturforschenden Gesellschaft in Danzig. Erster Theil (Danzig: Schreibersche Buchdruckerei, 1747), 175-304; idem, Zweiter Theil (Danzig und Leipzig: Lankische Buchhandlung, 1754), 355-460; idem, Dritter Theil (Danzig und Leipzig: Rengerische Buchhandlung, 1756), 492-556.

9 Januszajtis: "Gdańsk Pioneers of Metrology” (ref. 2), p. 739.

${ }^{10}$ Johann [Jean] Bernoulli, Reisen durch Brandenburg, Pommern, Preussen, Curland, Russland, und Polen in den Jahren 1777 und 1778. Erster Band. Zweite Abtheilung. Aufenthalt in Danzig (Leipzig: bey Casper Fritsch, 1779), p. 175.

${ }^{11}$ P.A. Hansen, Theorie der Pendelbewegung mit Rücksicht auf die Gestalt und Bewegung der Erde. Eine von der naturforschenden Gesellschaft zu Danzig am 3. Januar 1853 gekrönte Preisschrift (Danzig: 1853); reprinted in Neueste Schriften der Naturforschenden Gesellschaft in Danzig 5, No. 1 (Danzig: 1856).

${ }^{12}$ Andrzej Januszajtis, Zegar astronomiczny w Kościele Mariackim w Gdańsku [The Astronomical Clock in St. Mary's Church in Gdańsk] (Gdańsk: Wydawnictwo "Marpress," 1998); idem, Gdańsk Pioneers of Metrology" (ref. 2), pp. 743-744; idem, "The Gdańsk Clocks and Their Creators," TASK Quar. 4, No. 2 (2000), 301-310, especially 305-307; idem, Gdańskie zegary (ref. 3), pp. 39-45. ${ }^{13}$ Januszajtis, "Gdańscy pionierzy Fizyki“(ref. 4), pp. 14-19; idem, "Scientists in Old Gdańsk: $17^{\text {th }}$ and $18^{\text {th }}$ Centuries" (ref. 4), pp. 389-390.

${ }^{14}$ Andrzej Lisicki, "Johannes Hevelius as an observer," in Robert Głębocki and Andrzej Zbierski, ed., On the $300^{\text {th }}$ anniversary of the death of Johannes Hevelius. Book of the International Scientific 
Session (Wrocław, Warszawa, Kraków, Ossolineum: The Polish Academy of Science, 1992), pp. 23-42, especially pp. 33-40.

${ }^{15}$ Andrzej Januszajtis, "Mrs Hevelius - The First Female Astronomer in Poland," TASK Quar. 2, No. 1 (1998), 191-192.

${ }^{16}$ Quoted in Karolina Targosz, Jan Hewelusz Uczony-Artysta [Johannes Hevelius Scientist-Artist] (Wroclaw, Warszawa, Kraków, Gdańsk: Zaklad Narodowy im. Ossolińskich-Wydawnictwo, 1979), p. 101.

${ }^{17}$ Andrzej Januszajtis, "Peter Krüger (1580-1639) Gdańsk Scientist, Professor of the Academic Gymnasium," TASK Quar. 1, No. 1 (1997), 127-130; idem, "Scientists in Old Gdańsk: Prehistory and $16^{\text {th }}$ Century," ibid. 5, No. 2 (2002), 261-265, on 264-265.

${ }^{18}$ Heinrich Kühn: "Ausführliche Beschreibung einer neuen und volkommeneren Art von Wagen, etc.," Versuche u. Abhand. d. Natur. Gesell. Erster Theil (ref. 8), pp. 1-76.

${ }^{19}$ Andrzej Januszajtis, "Wydział Fizyki Technicznej i Matematyki Stosowanej [Faculty of Technical Physics and Applied Mathematics]," in Politechnika Gdańska, 50 lat, wczoraj, dziś i jutro (Gdańsk: 1995), pp. 89-100.

Faculty of Technical Physics and Applied Mathematics Technical University of Gdańsk

Narutowicza n11/12

80-952 Gdańsk, Poland

e-mail: andrzej.januszajtis@gmail.com 